Research Article

\title{
Numerical Investigation on the Ground Response of a Gob-Side Entry in an Extra-Thick Coal Seam
}

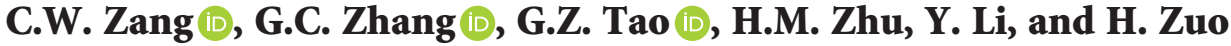 \\ College of Energy \& Mining Engineering, Shandong University of Science \& Technology, Qingdao 266590, China \\ Correspondence should be addressed to G.C. Zhang; zgchao2015@163.com
}

Received 27 August 2020; Revised 20 October 2020; Accepted 11 March 2021; Published 20 March 2021

Academic Editor: Giuseppe Ruta

Copyright (C) 2021 C.W. Zang et al. This is an open access article distributed under the Creative Commons Attribution License, which permits unrestricted use, distribution, and reproduction in any medium, provided the original work is properly cited.

\begin{abstract}
This study was aimed at the large deformation phenomenon of rock mass surrounding the gob-side entry driven in a $20 \mathrm{~m}$ extrathick coal seam. Taking tailgate 8211 as the engineering background, a numerical investigation was employed to analyze the deformation law of the gob-side entry. The study results are as follows. (1) Because the immediate roof was composed of weak coal mass with a thickness of $17 \mathrm{~m}$, the roof coal mass was vulnerable to fail with the effect of overlying strata pressure; thus, a visual subsidence of roof coal mass with a maximum convergence of $800 \mathrm{~mm}$ was observed in the field. (2) The bearing capacity of the coal pillar was significantly less than that of the panel rib, resulting in the pillar failing more easily under the ground pressure and then generating large-scale squeezing deformation. (3) The roof and panel rib were in a state of shear failure with a failure depth of about $5 \mathrm{~m}$. The coal pillar was entirely in a state of plastic failure. (4) A support scheme including an asymmetric anchor beam truss, roof angle anchor cable, and anchor cable combination structure was proposed. The field work confirmed that this support scheme could efficiently control the deformation and failure of the rock mass surrounding the gob-side entry. This study provides the theoretical basis and technical support for the control of rocks surrounding the gob-side entry in similar conditions.
\end{abstract}

\section{Introduction}

Thick and extra-thick coal seam resources are rich in China, and their reserves and production account for about $45 \%$ of the total [1]. Currently, thick and extra-thick coal seams have become the main coal seam for coal mining in China. Gobside entry is the most commonly used mining mode in thick and extra-thick coal seams, which mostly retains about 20 to $50 \mathrm{~m}$ wide coal pillars between adjacent panels to perform coal mining. In recent years, gob-side entry retained with 6-10 m wide coal pillar has begun to be popularized and applied in the thick coal seams $[2,3]$. However, due to the high abutment stress induced by mining activities, the roof and two sides of gob-side entries are prone to large-scale deformation and failure, as well as to vicious accidents, such as roof fall and rib spalling [4-7]. Thus, the stability control of gob-side entry has become a key factor restricting the high yield, efficiency, and safe mining of extra-thick coal seams.

In recent years, scholars have conducted a lot of beneficial research on the ground stability of gob-side entry in extra-thick coal seams. Zhang et al. presented a comprehensive field investigation of the ground response of a gate road subjected to high stress induced by extracting a $17 \mathrm{~m}$ thick coal seam [8]. Yu et al. pointed out failure modes of the gob-side entry and studied the influence of the failure structure on the stability of coal pillars [9]. Li et al. conducted a research into the balance conditions between the key rock blocks above the gob-side entry and proposed the entry support resistance quantitatively [10]. Shen et al. pointed out that the middle part of the roof is the main part to control the surrounding rock, and three kinds of targeted control technologies were put forward [11]. Feng et al. mentioned that strengthening coal pillars with high-strength bolts is of great significance to surrounding rock stability [12]. However, their studies suffer various limitations. The previous studies are mainly based on specific geological conditions. In reality, due to the complexity and difference of the geological conditions of various thick coal seams bases, the corresponding deformation and failure laws as well as its control method of the gob-side entry show great 
diversity [13-19]. In particular, there are few studies on the deformation law and control technology of gob-side entry in an extra-thick coal seam with a thickness of nearly $20 \mathrm{~m}$.

The objective of this study is to obtain a better understanding of stability principle of the gob-side entry in an extra-thick coal seam. In this study, FLAC3D numerical simulation software was used to analyze the distribution characteristics of the displacement, stress, and failure fields of a gob-side entry in an extra coal seam. Thus, the deformation and failure laws of the gob-side entry were obtained, and consequently, targeted control technologies are derived and applied in the field.

\section{Project Overview}

The test site was panel 8211 . The combined coal seams of \#5, $\# 3$, and $\# 3^{-1}$ were mined, which is $20.86 \mathrm{~m}$ thick in average. The average thickness of \# 5 coal seam was $13.76 \mathrm{~m}$, that of \#3 coal seam was $5.19 \mathrm{~m}$, and that of $\# 3^{-1}$ coal seam was $1.91 \mathrm{~m}$. The immediate roof was a coarse sandstone with an average thickness of $7.3 \mathrm{~m}$, having a gray-white, coarse-grained, and massive structure. The main roof was a fine sandstone, with an average thickness of $14.7 \mathrm{~m}$, having a gray-white, medium-to fine-grained, and massive structure. The immediate floor was mudstone, with an average thickness of $5 \mathrm{~m}$.

The test site was tailgate 8211 ; it was a rectangular section with a height of $5 \mathrm{~m}$ and a width of $3 \mathrm{~m}$. The coal pillar between the tailgate and the adjacent goaf of panel 8210 was $8 \mathrm{~m}$ wide, as shown in Figure 1. In actual engineering practice, to ensure the normal mining and excavation of the mine, tailgate 8211 had to be driven shortly after the panel 8210 was mined out. Thus, it became an urgent task to conduct research on the deformation and failure laws of the rock mass surrounding the tailgate 8211 .

\section{Numerical Analysis of the Stability Mechanism of the Gob-Side Entry in an Extra- Thick Seam}

It is well known that coal and rock mass may have plenty of discontinuous, which affect the stability of underground structures more or less, depending on the mechanical behavior of the discontinuities. Although continuum-based methods are incapable of modelling discontinuities, rock mass properties estimated from the intact cores properties using the Hoek-Brown criterion can be performed in the model, which are effective properties that accounted for the rock discontinuities. Therefore, in this section, FLAC3D simulation software was used to analyze the distribution characteristics of the displacement, stress, and failure fields during gob-side entry driven with a narrow coal pillar $[20,21]$.

It should be noted that, due to that those discontinuities were not considered in this study, the results generated by our model is expected to be slightly different with the actual value in reality. And future research is recommended to include the effects of this factor.
3.1. Numerical Model Establishment and Simulation Plan. Based on the actual geological production conditions of the panel 8211, a plane numerical simulation calculation model was established (see Figure 2). The model was $200 \mathrm{~m}$ long along the $x$-direction. The $z$-axis height of the model was $108.5 \mathrm{~m}$. The velocities of the horizontal and bottom boundary were set as 0 . The stress applied at the upper boundary was $7.5 \mathrm{MPa}$, representing the overburden pressure. The horizontal stress was applied in the $x$ - and $y$-directions of the model, and the lateral pressure coefficient was set to 1.2 .

Coal and rock mass are defined as the Mohr-Coulomb model. The rock/coal mass properties required in the numerical model were obtained from the properties of an intact core by using the RocLab 10.0 software program, which is based on the generalized Hoek-Brown failure criterion (see Table 1). The simulation process was as follows: initial stress calculation balance $\longrightarrow$ panel 8210 mining $\longrightarrow$ excavation of the gob-side entry.

3.2. Analysis of Simulation Results. The distribution of vertical and horizontal displacement contours is shown in Figure 3. The obtained results are as follows:

(1) Distribution Characteristics of Vertical Displacement: On the whole, vertical displacement of the roof coal body above the coal pillar (about $1200 \mathrm{~mm}$ on average) was much larger than that of the roof coal body of the entry (about $700 \mathrm{~mm}$ on average). From the surface of the entry to the depth of $3.5 \mathrm{~m}$, the roof coal body exhibited an overall sinking trend, with an average sinking of about $800 \mathrm{~mm}$, as shown in Figure 3(a). The abovementioned vertical displacement distribution characteristics can be attributed to the following reasons. (1) The thickness of the mining coal seam reached $20 \mathrm{~m}$, and the entry was driven along the coal seam floor. As a result, the immediate roof of the entry was a weak and fractured coal mass with a thickness of nearly $17 \mathrm{~m}$. It was prone to large-scale failure under strong mining activities, which would result in insignificant damage overall $[22,23]$. (2) Compared with the panel rib, the coal pillar rib had a smaller size and weaker bearing capacity. Under the same overburden movement, its plastic failure range was larger, which in turn led to a greater vertical displacement of the roof coal body above the coal pillar.

(2) Distribution Characteristics of Horizontal Displacement: From shallow to deep, the horizontal displacement of the panel rib gradually decreased, with the maximum displacement of $700 \mathrm{~mm}$ occurring in the middle of the panel rib. The coal pillar side also presented similar deformation characteristics, but the deformation value was larger than that of the panel rib side, reaching $900 \mathrm{~mm}$, as shown in Figure 3(b). The reason for this phenomenon is that the bearing capacity of the coal pillar was much smaller than that of the panel rib. Therefore, it was 


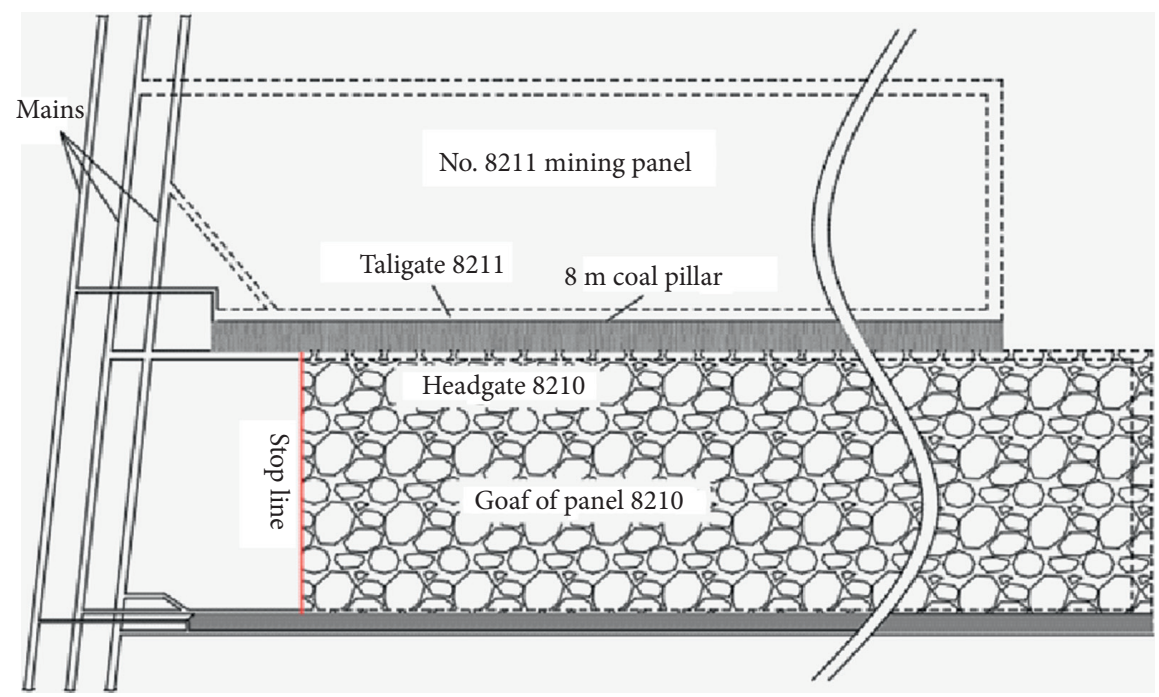

FiguRE 1: Diagram of the gob-side entry in section 8211.

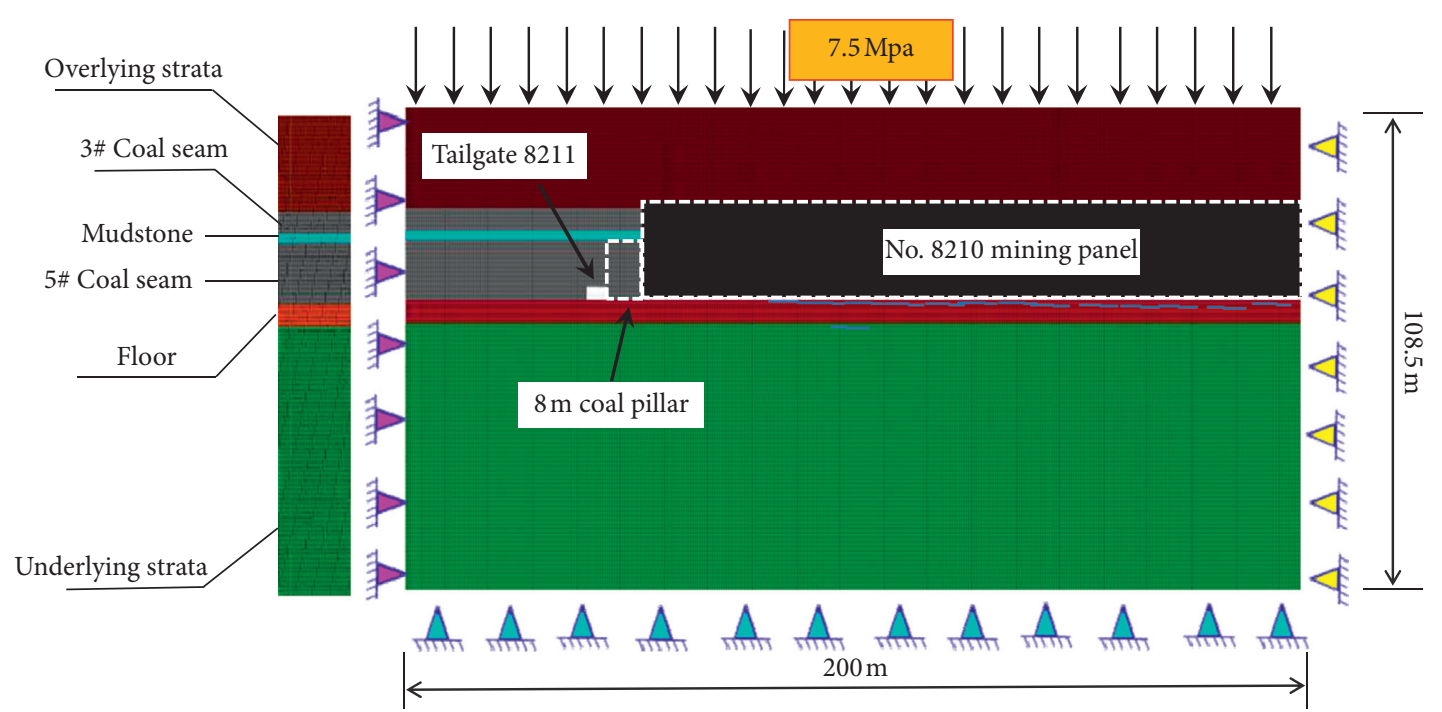

Figure 2: Numerical calculation model.

Table 1: Physical and mechanical parameters of strata.

\begin{tabular}{lccccc}
\hline Rock strata & Density $\left(\mathrm{g} \cdot \mathrm{cm}^{-3}\right)$ & Bulk modulus $(\mathrm{GPa})$ & Shear modulus $(\mathrm{GPa})$ & Cohesion $(\mathrm{GPa})$ & Internal friction angle $($ degree $)$ \\
\hline Floor rock & 2420 & 8.21 & 6.02 & 2.0 & 30 \\
Fine sandstone & 2500 & 3.47 & 2.63 & 1.6 & 26 \\
Coal rock & 1412 & 1.70 & 1.00 & 0.6 & 20 \\
Mudstone & 2200 & 6.47 & 5.64 & 2.2 & 30 \\
Overlying strata & 2100 & 0.95 & 6.50 & 3.0 & 35 \\
\hline
\end{tabular}

necessary to increase the supporting strength of the coal pillar in the field.

The plastic zone and vertical stress distribution of the surrounding rock of the gob-side entry in panel 8211 are shown in Figure 4.

(1) Distribution Characteristics of the Plastic Zone: It can be seen from Figure 4(a) that the roof coal rock mass was in a state of large-scale shear failure, and the failure depth was about $5 \mathrm{~m}$. The panel and coal pillar ribs were in shear failure models. The failure range of the panel side was about $5 \mathrm{~m}$, and the coal pillar rib was in a state of plastic failure. For the shallow coal body of the roof and two sides, it was in the tensile failure model.

(2) Distribution Characteristics of the Vertical Stress: From Figure 4(b), it can be seen that the shallow coal body of the entry was in a state of stress release, with 


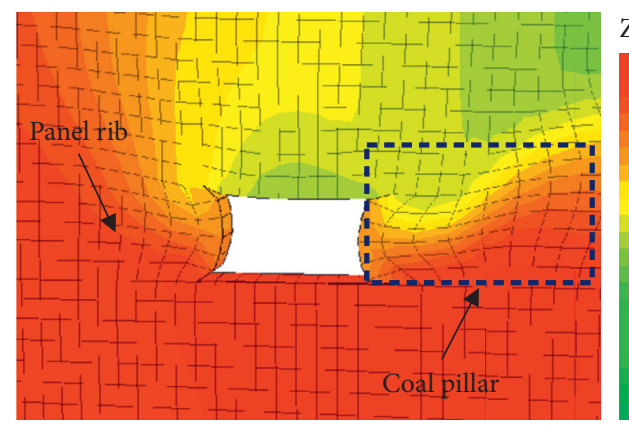

(a)

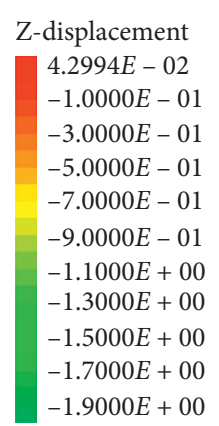

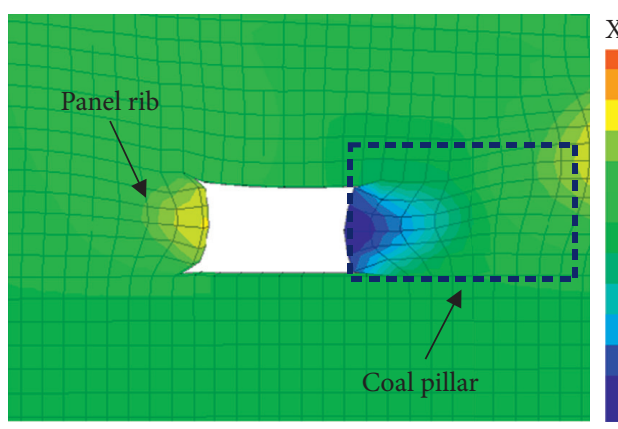

(b)

FiguRE 3: Displacement distribution developed around the gob-side entry in section 8211: (a) vertical displacement; (b) horizontal displacement.

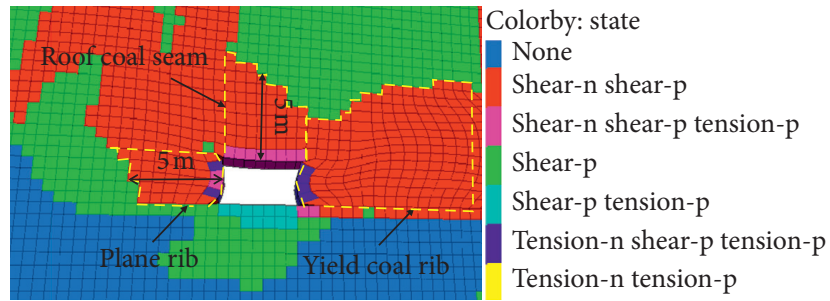

(a)

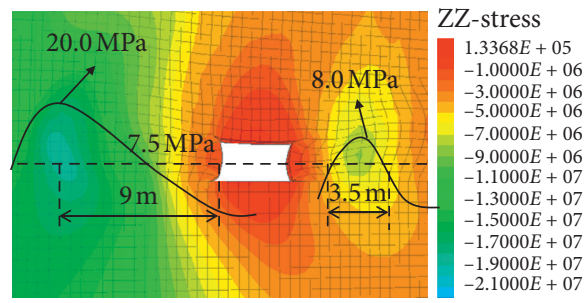

(b)

FigURE 4: Stress and plastic zone distribution developed around the gob-side entry in section 8211: (a) plastic zone; (b) vertical stress.

an average stress value of less than $1 \mathrm{MPa}$. For the panel rib, a peak stress of about $20 \mathrm{MPa}$ occurred $9 \mathrm{~m}$ away from the rib side, and the stress concentration factor was about 2.2. For the coal pillar rib, a maximum stress of $8 \mathrm{MPa}$ occurred, which was greater than the original rock stress by $7.5 \mathrm{MPa}$.

(3) Based on the distribution trend of the stress and plastic zone of the two ribs, it can be concluded that, although the coal pillar was totally in a state of shear failure, the stress of the coal body exceeded the original stress within $1.5 \mathrm{~m}$ of the central part of the coal pillar. This indicates that the coal pillar still had a certain degree of bearing capacity, which could meet the current demand for the ground control. However, it was still necessary to control the plastic damage range of the shallow coal body to avoid excessive horizontal displacement of the coal pillar.

\section{Ground Control of Surrounding Rock of the Gob-Side Entry}

4.1. Control Principle of Surrounding Rock of the Gob-Side Entry. Based on the actual geological production conditions and characteristics of the surrounding rock of the gob-side entry, the process of coal mass deformation and failure of the tailgate 8211 was analyzed as follows. (1) Tailgate 8211 was driven along the floor line of the coal seam, and the immediate roof was $17 \mathrm{~m}$ thick weak coal body with developed cracks. During entry excavation, affected by mining stress, the coal body would gradually undergo a plastic failure from shallow to deep, and consequently, the roof would sink and deform significantly. (2) Under the overlying strata movement, the coal pillar rib was all in the plastic failure state, and the bearing capacity of the coal pillar was smaller. Under strong mining stress, extrusion deformation occurred to the coal pillar rib, causing significant horizontal displacement.

Based on the above numerical analysis, to ensure the safety and stability of tailgate 8211 during its service period, the ground control should start from the following aspects $[24,25]$. (1) The coal pillar was totally in a state of plastic failure; as a result, its supporting force on the roof was small and it was easily failed. Therefore, improving the support intensity of the coal pillar is the key to control the deformation of the surrounding rock of the gob-side entry. (2) The roof of the gob-side entry was composed of a weak coal body. Affected by the strong mining action induced by the entry driving and the panel retreating, the coal body surrounding the entry would be severely failed and resulted in a relatively high crushing pressure. Therefore, it was necessary to adopt support components with a larger surface area, to improve the support strength of the surrounding rock of the surface.

4.2. Control Technology for the Gob-Side Entry with Narrow Coal Pillars in Extra-Thick Coal Seams. A support scheme, including high-strength bolts, strong roof anchors, and reinforced anchors for coal pillars, was determined, as shown in Figure 5. The specific parameters were as follows. 


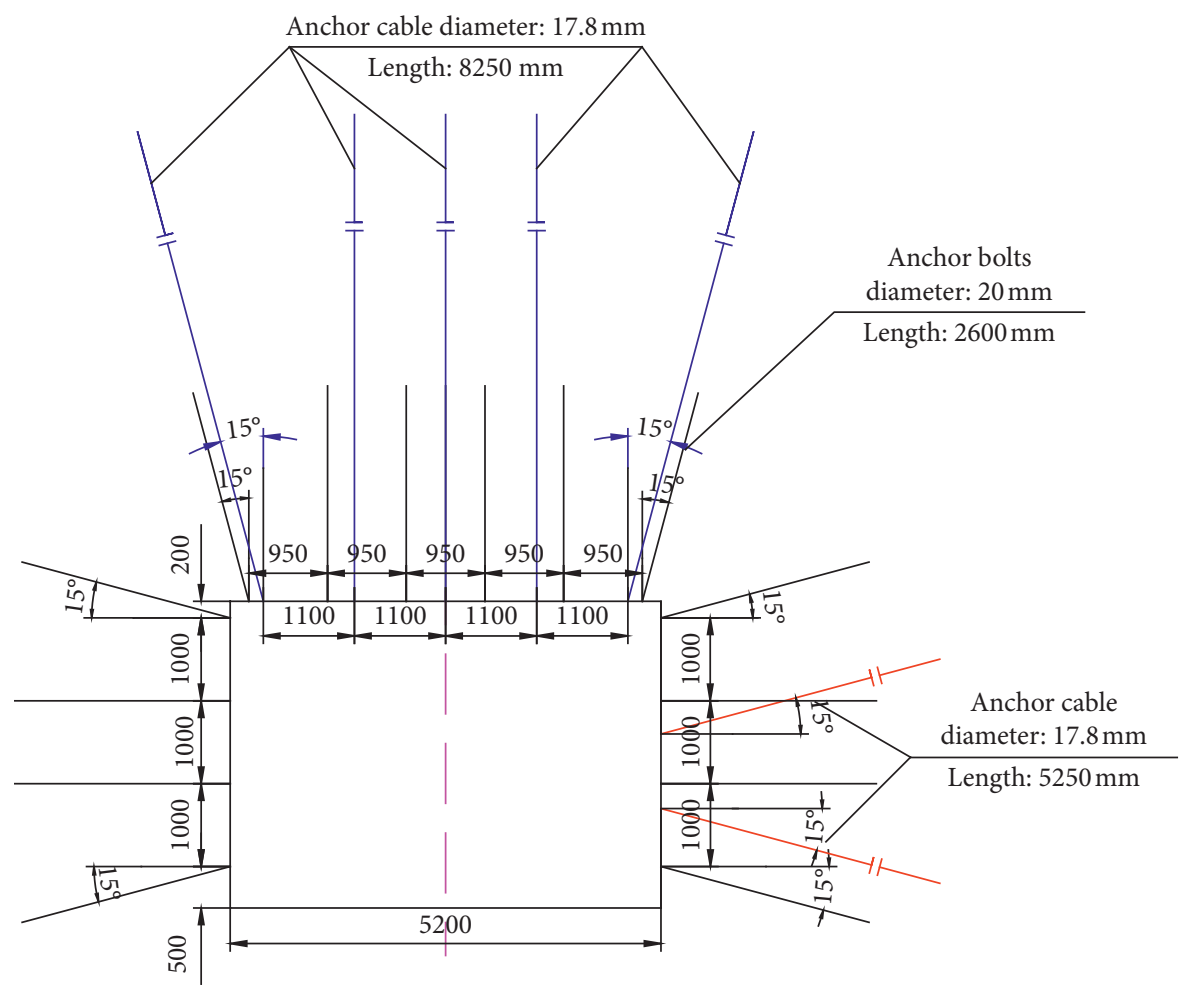

FIgURE 5: Support scheme of the gob-side entry.

The entry roof adopted a $\varphi 20 \times 2600 \mathrm{~mm}$ thread steel bolt, and the row spacing was $900 \times 900 \mathrm{~mm}$. Each row was arranged with six bolts. The bolts at the two sides were inclined 15 degrees outward, and the rest were arranged vertically. The bolt was connected by a reinforced ladder beam made of $\varphi 14 \mathrm{~mm}$ round steel welding.

Anchor cables with a diameter of $17.8 \times 8250 \mathrm{~mm}$ were selected, and the spacing between rows was $1050 \times 1800 \mathrm{~mm}$. Four anchor cables were arranged in each row. The anchor cables at the two sides were inclined 15 degrees outward, 16channel steel was used for connection, and the middle anchor cable was vertical to the roof. A $20 \times 2600 \mathrm{~mm}$ thread steel bolt was selected for the panel rib and coal pillar rib, with a row spacing of $1000 \times 900 \mathrm{~mm}$, and each row had four bolts. The anchor rod at the roof was inclined 15 degrees upward, and the anchor rod at the floor was inclined 15 degrees downward. The rest were arranged vertically on two sides and connected by steel beams welded by $\varphi 12 \mathrm{~mm}$ round steel. On the coal pillar rib, the prestressed anchor cables were arranged in the middle of two adjacent rows of bolts with a distance of $900 \mathrm{~mm}$. The upper anchor cables were inclined 15 degrees upward, and the bottom anchor cables were inclined 15 degrees downward.

\section{Engineering Application}

During the excavation of the tailgate 8211, four measuring stations were arranged in the entry with a distance of $50 \mathrm{~m}$. The JSS30 A digital display convergence meter was used for measurements. The displacement of the entry roof and two sides during excavation period is shown in Figure 6. It can be

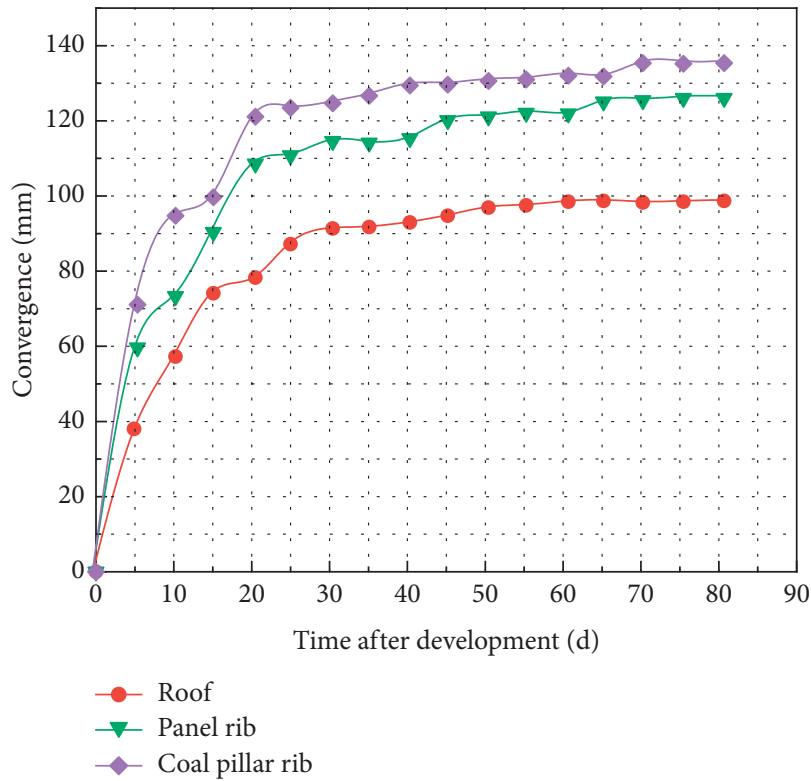

FIgURE 6: Deformation monitoring of the surrounding rock during roadway excavation.

seen that the surface displacement of the entry showed a changing trend of "coal pillar rib > solid coal rib> roof." Finally, the deformation of the coal pillar was $131 \mathrm{~mm}$, the deformation of the panel rib was $125 \mathrm{~mm}$, and the subsidence of the roof was $99 \mathrm{~mm}$. It can be seen that the deformation of the surrounding rock of tailgate 8211 was within a controllable range, which could meet the needs of 


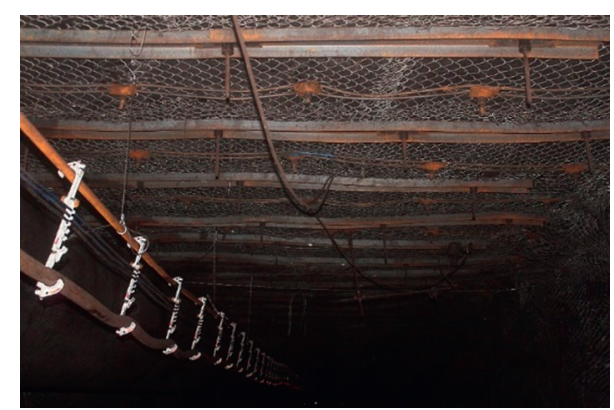

FIGURE 7: Control effect of the surrounding rock.

normal panel mining. The photo of site support effect is shown in Figure 7 . It should be noted that the applicability of the proposed support scheme on other coal mines needs to be studied because every coal mine may have different geological and mining conditions, which greatly affect the support parameters design. Further case studies are needed in order to deliver some general principles of support scheme design.

\section{Conclusion}

(1) Because the immediate roof was composed of weak coal mass with a thickness of $17 \mathrm{~m}$, the roof coal mass was vulnerable to failure on a large scale with the effect of overlying strata pressure; thus, a visual subsidence of roof coal mass with a maximum convergence of $800 \mathrm{~mm}$ was observed.

(2) The bearing capacity of the coal pillar was significantly less than that of the panel rib, resulting in the pillar failing more easily under the ground pressure and then generating large-scale squeezing deformation along the horizontal direction.

(3) On the basis of the coal mine's geological production conditions and the deformation and failure laws of the surrounding rock along the gob-side entry, a support scheme including an asymmetric anchor beam truss, roof angle anchor cable, and anchor cable combination structure was proposed.

It should be noted that the optimal support scheme and coal pillar size strongly depend on the geological and mining conditions. In addition, this study was only based on a specific coal mine model. Further case studies are needed in order to deliver some general principles of gob-side gate road stability design. However, the modelling procedures presented in this study are necessary in the design of yield pillars in other coal mine.

\section{Data Availability}

The data used to support the findings of this study are available from the corresponding author upon request.

\section{Conflicts of Interest}

The authors declare that they have no conflicts of interest.

\section{References}

[1] Y. Chen, S. Ma, and Y. Yu, "Stability control of underground roadways subjected to stresses caused by extraction of a $10-\mathrm{m}$ Thick coal seam: a case study," Rock Mechanics and Rock Engineering, vol. 50, no. 9, pp. 2511-2520, 2017.

[2] H. Yan, F. He, T. Yang, L. Li, S. Zhang, and J. Zhang, "The mechanism of bedding separation in roof strata overlying a roadway within a thick coal seam: a case study from the Pingshuo Coalfield, China," Engineering Failure Analysis, vol. 62, pp. 75-92, 2016.

[3] G.-C. Zhang, Y.-L. Tan, S.-J. Liang, and H.-G. Jia, "Numerical estimation of suitable Gob-Side filling wall width in a highly gassy longwall mining panel," International Journal of Geomechanics, vol. 18, no. 8, Article ID 04018091, 2018.

[4] S.-L. Wang, S.-P. Hao, Y. Chen, J.-B. Bai, X.-Y. Wang, and $\mathrm{Y}$. $\mathrm{Xu}$, "Numerical investigation of coal pillar failure under simultaneous static and dynamic loading," International Journal of Rock Mechanics and Mining Sciences, vol. 84, pp. 59-68, 2016.

[5] M. Shabanimashcool and C. C. Li, "Analytical approaches for studying the stability of laminated roof strata," International Journal of Rock Mechanics and Mining Sciences, vol. 79, pp. 99-108, 2015.

[6] C.-J. Hou and X.-H. Li, "Stability principle of big and small structures of rock surrounding roadway driven along goaf in fully mechanized top coal caving face," Journal of China Coal Society, vol. 26, pp. 1-7, 2001.

[7] W. Li, J. Bai, S. Peng, X. Wang, and Y. Xu, "Numerical modeling for yield pillar design: a case study," Rock Mechanics and Rock Engineering, vol. 48, no. 1, pp. 305-318, 2015.

[8] G. C. Zhang, Z. J. Wen, S. J. Liang et al., "Ground response of a gob-side entry in a longwall panel extracting $17 \mathrm{~m}$-Thick coal seam: a case study," Rock Mechanics and Rock Engineering, vol. 53, no. 2, pp. 497-516, 2020.

[9] B. Yu, Z. Zhang, T. Kuang, and J. Liu, "Stress changes and deformation monitoring of longwall coal pillars located in weak ground," Rock Mechanics and Rock Engineering, vol. 49, no. 8, pp. 3293-3305, 2016.

[10] X. Li, M. Ju, Q. Yao, J. Zhou, and Z. Chong, "Numerical investigation of the effect of the location of critical rock block fracture on crack evolution in a gob-side filling wall," Rock Mechanics and Rock Engineering, vol. 49, no. 3, pp. 1041-1058, 2016.

[11] W.-L. Shen, M. Wang, and Z.-Z. Cao, "Mining-Induced failure criteria of interactional hard roof structures: a case study," Energies, vol. 12, no. 15, pp. 1-17, 2019.

[12] G. Feng, P. Wang, and Y. P. Chugh, "Stability of gate roads next to an irregular yield pillar: a case study," Rock Mechanics and Rock Engineering, vol. 52, no. 8, pp. 2741-2760, 2019.

[13] G. Zhang, L. Chen, Z. Wen et al., "Squeezing failure behavior of roof-coal masses in a gob-side entry driven under unstable overlying strata," Energy Science \& Engineering, vol. 8, no. 7, pp. 2443-2456, 2020.

[14] H. Wang, S. Xue, Y. Jiang, D. Deng, S. Shi, and D. Zhang, "Field investigation of a roof fall accident and large roadway deformation under geologically complex conditions in an underground coal mine," Rock Mechanics and Rock Engineering, vol. 51, no. 6, pp. 1863-1883, 2018.

[15] G.-C. Zhang, F.-L. He, Y.-H. Lai, and H.-G. Jia, "Ground stability of underground gateroad with $1 \mathrm{~km}$ burial depth: a case study from Xingdong coal mine, China," Journal of Central South University, vol. 25, no. 6, pp. 1386-1398, 2018. 
[16] G.-C. Zhang, F.-L. He, H.-G. Jia, and Y.-H. Lai, "Analysis of gateroad stability in relation to yield pillar size: a case study," Rock Mechanics and Rock Engineering, vol. 50, no. 5, pp. 1263-1278, 2017.

[17] B.-Y. Jiang, S.-T. Gu, L.-G. Wang, G.-C. Zhang, and W.-S. Li, "Strainburst process of marble in tunnel-excavation-induced stress path considering intermediate principal stress," Journal of Central South University, vol. 26, no. 4, pp. 984-999, 2019.

[18] X.-L. Li, Z.-Y. Cao, and Y.-L. Xu, "Characteristics and trends of coal mine safety development," Energy Sources, Part A: Recovery, Utilization, and Environmental Effects, 2020.

[19] G.-C. Zhang, C.-W. Zang, M. Chen et al., "Ground response of entries driven adjacent to a retreating longwall panel," International Journal of Rock Mechanics and Mining Sciences, vol. 138, Article ID 104630, 2021.

[20] S. Shnorhokian, H. S. Mitri, and D. Thibodeau, "A methodology for calibrating numerical models with a heterogeneous rockmass," International Journal of Rock Mechanics and Mining Sciences, vol. 70, pp. 353-367, 2014.

[21] H. Yavuz, "An estimation method for cover pressure re-establishment distance and pressure distribution in the goaf of longwall coal mines," International Journal of Rock Mechanics and Mining Sciences, vol. 41, no. 2, pp. 193-205, 2004.

[22] C. C. Li, "Field observations of rock bolts in high stress rock masses," Rock Mechanics and Rock Engineering, vol. 43, no. 4, pp. 491-496, 2010.

[23] W. P. Huang, Q. Yuan, Y. L. Tan et al., "An innovative support technology employing a concrete-filled steel tubular structure for a 1000-m-deep roadway in a high in situ stress field," Tunnelling and Underground Space Technology, vol. 73, pp. 26-36, 2018.

[24] Z.-Z. Zhang, W.-J. Wang, S.-Q. Li et al., “An innovative approach for gob-side entry retaining with thick and hard roof: a case study," Technical Gazette, vol. 25, no. 4, pp. 1028-1036, 2018.

[25] Z. Zhang, M. Deng, X. Wang, W. Yu, F. Zhang, and V. D. Dao, "Field and numerical investigations on the lower coal seam entry failure analysis under the remnant pillar," Engineering Failure Analysis, vol. 115, Article ID 104638, 2020. 